AGRO EKONOMI, Vol 30, Issue 1, June 2019, Page.28-40

DOI : http://doi.org/10.22146/ae.43755

ISSN 0215-8787 (print), ISSN 2541-1616 (online) Available at https://jurnal.ugm.ac.id/jae/

\title{
THE EVALUATION OF SEVERAL ALTERNATIVE POLICIES' IMPACT ON THE MANDARIN (CITRUS RETICULATA) INDUSTRY IN INDONESIA: A SYSTEM DYNAMICS ANALYSIS
}

\author{
Lyli Mufidah ${ }^{1}$, Fatimah Mohamed Arshad $^{2}$, Shaufique Fahmi Sidique ${ }^{2}$, Agus \\ Sugiyatno ${ }^{1}$ Abdulla Ibragimov ${ }^{2}$ \\ ${ }^{1}$ Indonesian Citrus and Subtropical Fruits Research Institute (ICSFRI), \\ ${ }^{2}$ Institute of Agricultural and Food Policy Studies \\ Jl. Raya Tlekung No.1, Junrejo, Batu \\ Putra Infoport Jl.Kajang Puchong 43400 UPM Serdang Selangor \\ lyli.mufidah@gmail.com
}

Submitted : 25 February 2019; Revised : 29 April 2019; Accepted 8 July 2019

\begin{abstract}
The increase in imports and the decline in Indonesia's production triggered the government's intervention in the form of non-tariff barriers. This will surely make a change in Indonesia's mandarin landscape industry. Therefore, this paper aims to construct structured factors building the mandarin industry and attempts to evaluate the impact of several alternative policies, including the non-tariff barriers imposed, in the purpose to find the policies sustaining the industry in the future. System dynamics are employed due to their ability to accommodate time delay and reciprocal relationships between sub-systems found in the industry. The time series data of mandarin from BPS were used in this research from 1999 to 2012, which includes production, productive area, productivity, price, local consumption and import. The first step is to construct the existing pattern of the mandarin industry in Indonesia. Afterward, six different scenarios were simulated, including the non-tariff barriers; and they were compared for their ability to sustain the Indonesian mandarin industry. The ability was assessed from the relative value, production, expected profits and import value. The analysis results recommend the government to pay more attention to the disease management and to improve the ratio of agricultural extension agents to areas, which can lead to a more significant impact on the mandarin industry in Indonesia, even with the gradual elimination of non-tariff barriers.
\end{abstract}

Keywords: cvpd/ huanglongbing, disease management, Indonesia's mandarin industry, nontariff barrier, system dynamics

Mufidah, L., Arshad, F.M., Sidiq, S.F., \& Ibragimov, A.S.A. (2019) The Evaluation of Several Alternative Policies' Impact on The Mandarin (Citrus Reticulata) Industry in Indonesia: A System Dynamics Analysis. Agro Ekonomi 30(1): 28-40 


\section{INTRODUCTION}

The mandarin industry is one of the important fruit sectors in Indonesia, supporting approximately 65,000 Indonesian farmers (Nurhadi, 2015). It still suggests a higher economic return with benefits over cost ratio of 1.8 in medium scale cultivation; it is the third most consumed fruit in Indonesia. Marks (2012) asserted that as Indonesian household expenditures grow, the expenditure per capita for fruits also increase; it also includes the mandarin. It indicates that people are aware of the health and nutritional benefits of their daily consumption, according to their purchasing power.

In international trades, citrus is ranked first among fruit crops based on its value (Thohirah et al., 2009). One of the fundamental aspects in the Indonesian citrus market competition is the imported goods' price, which is cheaper compared to the local one, from 2004 to 2012; in that, the difference was Rp 5,372 per kg on average. Researches highlighted the ASEAN China Free Trade Agreement (ACFTA), which gave exceptions to the mandarins from China; which is the largest Indonesian mandarin import supplier, with a 5\% import tariff in 2004 and zero afterward. This leads to the assumption that consumers are being slowly directed to the imported mandarins, because of the lower price.
It shows a trend in consuming the imported mandarins instead of the local ones, even though it is still in a small scale.

This small scale is quite a concern, as it appears that the import value reached 176 million USD in 2012. It creates a focus on the development of mandarin products as a substitute of the imported ones. Presumably, the consumers' shift to the imported mandarins also triggered the government to protect and provide a stimulus for the local production; it is done by issuing non-tariff barriers in the form of tightening import procedures (the trade ministry regulation no.16 / M-DAG / PER / 4/2013), the minister of agriculture regulation no.86 / OT.140 / 8/2013), reducing the formal entrance (the minister of agriculture regulation No.42 / / OT.140 / 6/2012) and supporting the local products to have an access to the modern stores (the trade ministry regulation no.56 / M-DAG / PER / 9/2014). This non-tariff policy will somewhat affect the mandarin landscape industry.

The dynamic system model is used to analyze the impact of policy because it accommodates time delays and circular causality between the sub-systems found in this industry. In addition to nontariff policies, $R \& D$ policies and disease management will also be involved in this approach in order to view which policies are more influential. 
The disease management and the addition of agricultural extension agents are included in the system to pay attention to several cases in which citrus vein phloem degeneration (CVPD) previously occurred; it is one of the citrus diseases causing a decline in production. Around $31 \%$ of the production plant in 2,629 of 13,000 ha area had been attacked by CVPD and experienced loss up to 120 billion per year. CVPD disease caused by Liberobacter is a negative group of alpha subdivision of Proteobacteria (Meitayani et al., 2014). According to Bassanezi et al., (2011) and Spreen et al., (2014), CVPD can reduce productions by the productivity and land; it can also increase the production costs.

Several studies have used the system dynamics approach to evaluate policies on agricultural commodities. Hidayatno, et.al (2011) also Abdulla, et.al (2014) reviewed palm oil commodities related to the government policies that could maintain the bio-diesel industry and the impact of export-duty reduction. Rozman, et.al (2015) used the approach to examine the lever factors that support the conversion of conventional agriculture to organic one, while $\mathrm{L}, \mathrm{Fu}$ Jia et.al (2012) used system dynamics in providing solutions to policies that can provide improvement in the existing agricultural systems. Regarding the citrus commodities, Arsanti, et.al (2015) developed a priority in policy alternatives (area expansion and disease prevention) to improve tangerine production in the district of Karo. Ferreira, et.al (2016) conducting research on integrated orange agribusiness system in Brazil which used system dynamics because of its ability to quantify the value of the proposed model benefits.

This research was different with previous research, where used system dynamics approach in order to see the structural factors that build Indonesia's mandarin industry and to evaluate the impact of several alternative policies in this industry. The clostes research that was done by (Arsanti et al., 2015) only considerd at two policies, namely additional land and increase in funding for contolling plant pest. Arsanti restricted the production center in Karo district, while consumption in DKI Jakarta, and exclude the mandarin/ tangerine life cycle which will definitely affect demand and supply because time delay was needed Moreover, this research was also utilized to detect the root cause of the production decline and to figure out how to sustain Indonesia's mandarin industry in the future.

This paper aims to construct structured factors building the mandarin industry and attempts to evaluate the impact of several alternative policies, 
including the non-tariff barriers imposed, in the purpose to find the policies sustaining the industry in the future

\section{METHODS}

In this study, the development process of system dynamics model have the following stages: (1) the problem of articulation, (2) the formulation of dynamic hypotheses about the causes of the problem, which requires an understanding of the character and macroscopically structure of the industry (3) the formulation of a simulation model, (4) the test of model or model validation and (5) the policies of designing and evaluating for improvement (Ernawati et al., 2013; Yunna et al., 2015).

The process was started from determining the time horizon, which was set during 1999-2034, with reference modes from 1999 to 2012; it was based on the data obtained from the Central Bureau of Statistics (also called BPS -
Badan Pusat Statistik). The data were chosen from that period since the earlier ones (from 1961-2012) from FAO did not separate between the mandarin and sweet orange. During the period of 1999 2012, there was a shift in production indicating a macroeconomic structural change.

The dynamic hypothesis was presented in the system diagram of the Indonesian mandarin industry model, which is represented in the causal loop diagram (CLD) and formulated to stock and flow diagrams (Figure 2). The validation procedure used was based on Adipraja \& Sulistyo, (2018) and Qudrat-Ullah (2012), in which the historical fit of the Indonesian mandarin industry model was tested using the root mean square percentage error (RMSPE) and the quality of statistics, which is a decomposition of the mean square error (MSE) into systematic (Um), unequal variations (Us) and unsystematic (Uc) components. This

Table 1. Simulation Scenario

\begin{tabular}{lccccc}
\hline & \multicolumn{5}{c}{ Policy Strategies } \\
\cline { 2 - 4 } Scenario & $\begin{array}{c}\text { Domestic } \\
\text { Protection Policy } \\
(2012)\end{array}$ & $\begin{array}{c}\text { Stimulus } \\
\text { Policy }(2016)\end{array}$ & $\begin{array}{c}\text { R\&D Policy } \\
(2016)\end{array}$ & Fund & $\begin{array}{c}\text { Improvement extension } \\
\text { agent-area ratio }\end{array}$ \\
\hline S1 (BAU) & $\sqrt{n}$ & - & - & - & - \\
S2 & $\sqrt{ }$ & $\sqrt{ }$ & - & - & - \\
S3 & $\sqrt{ }$ & $\sqrt{ }$ & $\sqrt{ }$ & - & - \\
S4 & $\sqrt{ }$ & $\sqrt{ }$ & $\sqrt{ }$ & $\sqrt{ }$ & $\sqrt{ }$ \\
S5 (FM) & $-($ started 2013) & - & - & - & - \\
S6 & $-($ started 2013) & - & $\sqrt{ }$ & $\sqrt{ }$ & $\sqrt{ }$ \\
\hline
\end{tabular}


calculation was performed on 6 six variables: production, productive area, price, productivity, local consumption, and import consumption.

In analyzing the suitable policy scenarios, the R\&D policy was included in the expected growth rate of productivity, determined by the existing Mandarin Research and Development (R \& D). On the other hand, the disease management was focused on the extension program, including an accurate assessment of technology adoption which is a means of prevention.

The overall scenarios were summarized in Table 1, revealing the difference in policy strategies. The results of those six scenarios were compared on the basis of their ability to sustain the Indonesian Mandarin industry, assessed from the impact of their application on the relative value, production, expected profits and import value.

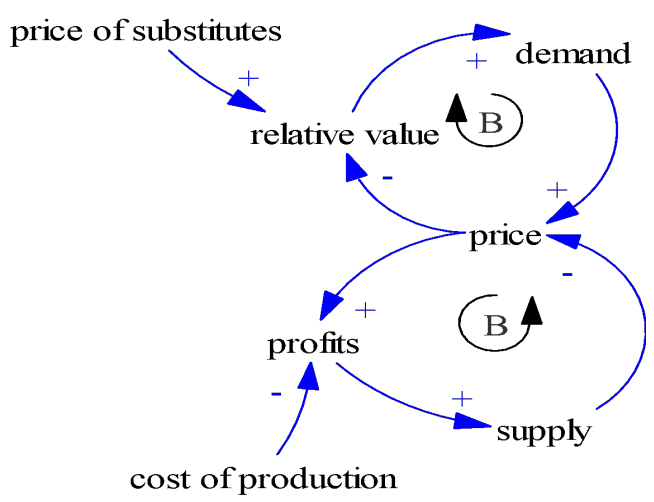

Figure 1. The Market Feedback Structure.

Source: (Sterman, 2004)

\section{RESULTS AND DISCUSSION}

\section{Model Formulation}

The model is differentiated into two sub-systems, which are the local and imported mandarin; each sub-system has a production and consumption flow in Indonesia. The structure analysis of market feedback system used is based on Figure 1, in which the price represents the local price and the substitutes represent the import one. The import price is estimated to be $20 \%$ higher after the implementation of the domestic protection policy (Marks, 2012). Figure 1 shows that the commodity was relatively low and also led the consumers to the substitute or quit consuming the product.

The relative value was obtained from the substitutes compared to the commodity price. The decline of the relative value will reduce the commodity demand; prices went down and in turn raised the relative value. Nonetheless, the rising price of the commodity caused the expected profit to increase; it depended on the amount of the cost of production. More profit would have expanded the supply. However, the greater supply would have made the bid for the price declined.

Based on the background, the researchers attempted to compile the stock and flow of the Indonesian mandarin industry, on the assumption 


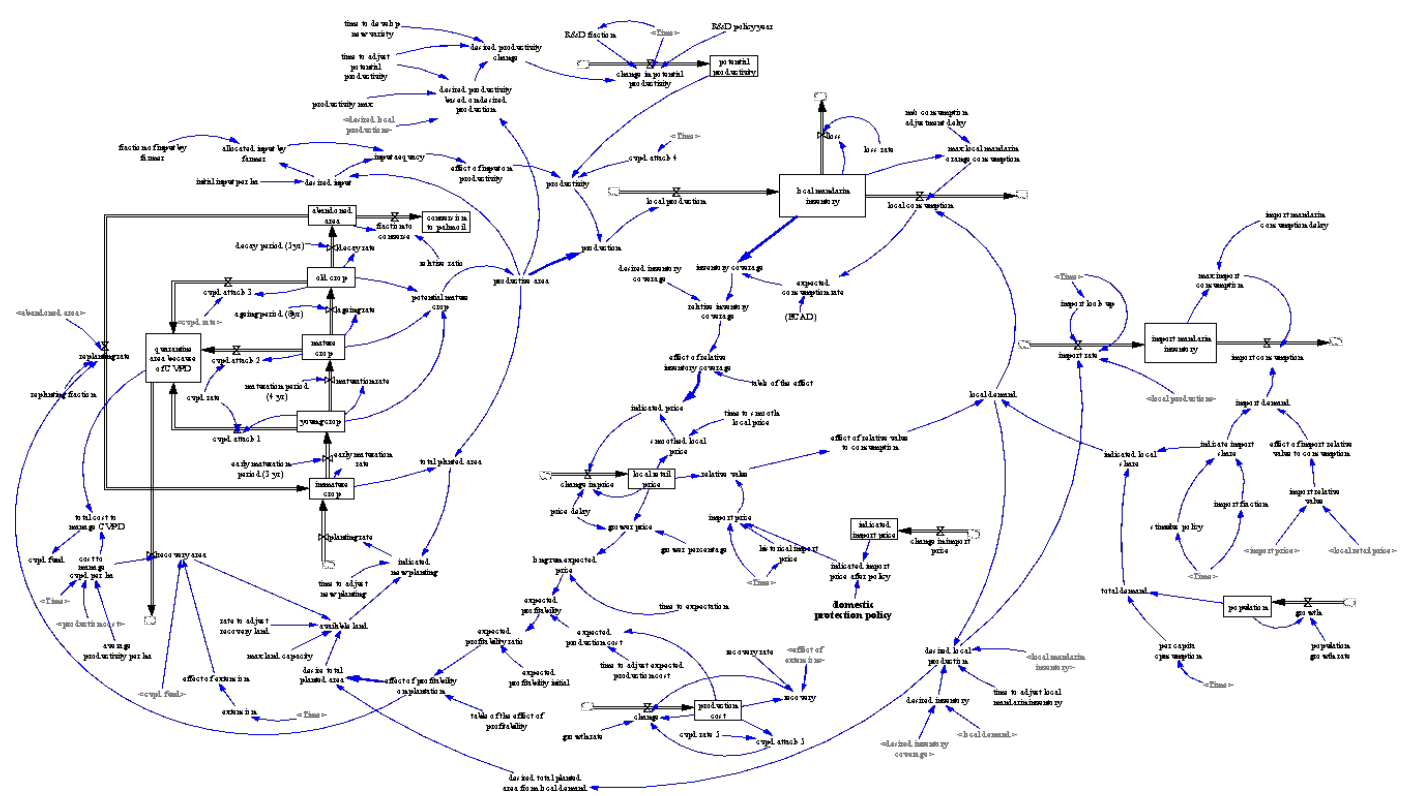

Figure 2. The Stock and Flow of the Indonesian Mandarin Industry

that other factors outside the system were considered constant (weather, quality, consumer tastes, etc.). This utilized the approach of a system's isolating part, which was also used by $\mathrm{P}$, Kaufmann et al., (2009) and Teimoury et al., (2013). The factors added were those which are important and influential (disease management; R \& D; nontariff policies in the form of domestic protection policy affecting the import prices and stimulus policies affecting the import demand).

The root mean square percent error (RMSPE) for the two key variables in the system, namely productivity, and price in the model that were built (Figure 2.) displayed small value ( 9 and $7 \%$ ). Therefore, the inequality statistics was calculated to ensure the data, followed by the historical fit of the simulation results data analysis. The calculation results show that the six variables are followed the historical pattern, with $\mathrm{Um}=0$ for production, productive area, productivity and price), 0.4 for import consumption, and 0.5 for local consumption. It indicates that the model is able to track all these variables.

\section{Simulation Results}

The results of the six scenarios were assessed from the relative value, production, expected profits and import values. They are described as follow:

\section{Relative Value}

The simulation results from the relative value are illustrated in Figure 3 . The relative value represents the 
comparison between the mandarin import and the local prices. The higher relative value can compete with the import price. The simulation shows that after the implementation of the policy, the relative value moved upward after undergoing a decline in 2011.

The relative value results for S1, S2, S3, S4, S5, and S6 were 1.7\%, $1.17 \%, 1.18 \%: 2.8 \%, 0.9 \%$, and $2.6 \%$ (respectively). The scenarios experiencing improvements from business as usual (S1) only S4 and S6, which implemented R\&D and disease management policy. In S5, which domestic protection and stimulus policy were not applied, the movement in the first fifteen years was lower than other four scenarios (S1, S2, S3, S4), and it was even lower than S5 in the first eight years. After that, it experienced an increasing trend and was able to achieve a relative value compared to four other scenarios (S1, S2, S3 and S5), of which the amount was 0.77 in 2034. This result shows the importance of $R \& D$ and disease management policy, which cover funding and improvement extension agent-area ratio (Pardey et al., 2012).

Wossen et al., (2017) found that there is positive impact of the extension in technology adaption. It is also supported by Pan et al., (2018) research which shows the role of extensions through providing information and training that can increase agricultural productivity in poor farmers, where several studies show that the level of technology adoption, especially in developing countries is still slow ( Duflo et al., 2011; Udry, 2010). Referring to the law No.19/2013 on the protection and empowerment of farmers in the village, every farm the region has at least one person to supervise 100 ha of the agricultural land area. The agriculture extension agent (AEA) available in Indonesia has currently undergone a shortage of 39,480 from 47,418 personnel.

\section{Production}

Although the trend fluctuates, it displays an increase in the average

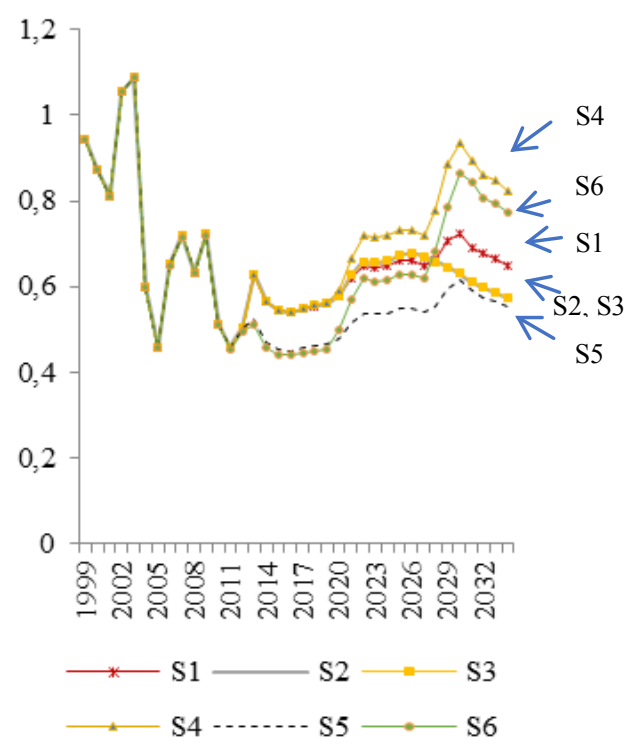

Figure 3. The Simulation Results of the Relative Value on 6 Scenarios, 19992034 


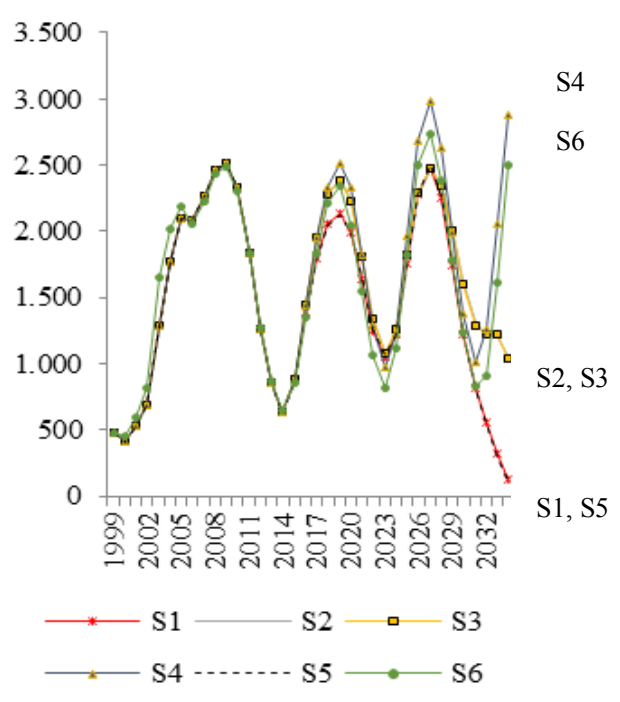

Figure 4. The Simulation Results of Local Production on 6 Scenarios ('000 t), 1999-2034

annual rate of growth; except for S1 and S5, which after 2027, continued to decrease. The average annual rates of growth during 2012-2034 for S1, S2, S3, S4, S5 and S6 were (respectively): $6.1 \%, 0.7 \%, 0.7 \%, 7 \%, 6.5 \%$ and $6.9 \%$. The decline occurred in S1 was caused by the decreasing land availability and the increase in the production cost due to the CVPD attack (Meitayani et al., 2014; Nurhadi, 2015). Thus, it made the triggering factor for the mandarin planting area expansion lowered. The percentage was higher due to the absence of a protection policy, causing the price of local mandarin production to compete with mandarin imports.

This is reflected in S5 relative movement, which is lower than the five other scenarios. The scenario that was implemented by the management and the improvement of agent area ratio, along with the R \& D policy, appeared to give a real effect on the production increase in 2034, i.e. 2.8 and 2.5 million tons for S4 and S5, respectively; of which the previous amount was about 1.3 million tons in 2012.

\section{Expected Profit}

The simulation results in Figure 5 show two main patterns: (1) the decline after a certain year and (2) the increase trend. The first pattern occurred in S1, S2, S3, and S5, which declined after 2029, 2032, 2031 and 2024, respectively; it led to negative profit in 2034. The second pattern appeared in S4 and S6, despite a slight decline during 2029-2031. In this simulation, the expected profit was a grower price minus the expected cost. The simulation results indicate that the increase in import cost and $\mathrm{R}$ \& D is not able to provide an optimal effect, if it is not accompanied by disease management and the increase in agentarea ratio. It is because CVPD attacks are expected to increase the cost of production. The movement of expected production costs on six scenarios can be seen in Figure 6.

In S4 and S6, the average annual rates of growth from 2013 to 2034 were $7.28 \%$ and $5.64 \%$, respectively. In $\mathrm{S} 4$, the expected profits increased 


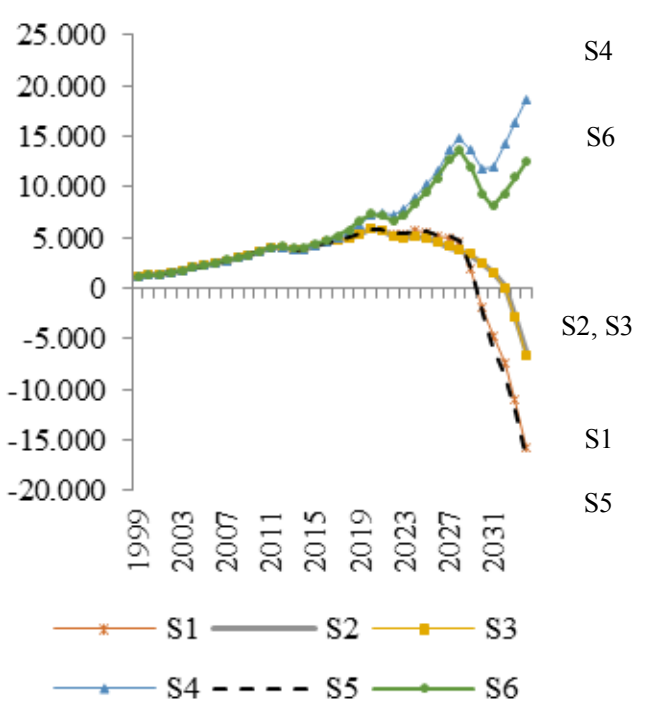

Figure 5. The Simulation Results of the Expected Profit on 6 Scenarios (IDR/ kg), 1999-2034

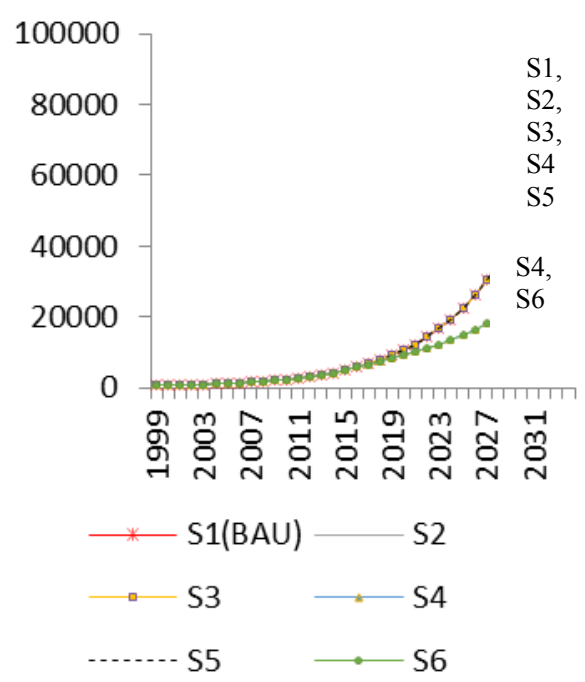

Figure 6. The Simulation Results of the Expected Cost on 6 Scenarios (IDR/kg), 1999-2034

from $\mathrm{Rp} 1,166.00$ per $\mathrm{kg}$ in 1990 to $\mathrm{Rp} 18,683.00$ per kg in 2034 ; it is $48 \%$ higher than in S6, which was estimated at Rp12,623.00 per kg. However, S6 provides an overview that the industry is capable of facing the free market when supported by R\&D, disease management implementation, and improvement in the extension agent-area ratio which is useful for the technological adaption of the R\&D research in terms of productivity and disease.

\section{Import Value}

The simulation shows that after the implementation of the domestic policy in 2012, the import was reduced yet rebounded in 2014, and decreased again after 2016 when the stimulus policy was applied. It is worth to notice that the same pattern during 2012-2017 also appeared when the protection policy was not implemented (S5 and S6). In S6, where the R \& D policy and disease management along with the agent-area ratio improvement were implemented under the free market conditions, the import rate was able to be suppressed, albeit with a larger import value.

The results of S1, S2, S3, S4, S5, and S6 indicate that the ability of local production to meet consumer demand plays a major role in suppressing the import rate. As compared to S1, in which only applies the domestic protection policy without strengthening the mandarin local production, the import value in 2034 was estimated to reach 3.2 million tons; it is $1,398 \%$ greater than the import value under S6. 


\section{CONCLUSION AND SUGGESTION}

The results show that by implementing all policies will give the best results. However in here, it is seen that the policy of handling diseases management and R\&D is the policy that touches the root of the problem, because it can increase relative value. It becomes an indication of the ability of local products to compete with imported products even with the removal of the domestic protection and stimulus policy.

This study suggests that: (a) the government can implement these four policies (domestic protection, stimulus, R\&D and disease management policy) at the beginning to strengthen the industry; (b) the protection (both tightening import procedure and stimulus policy) can be gradually reduced when competitiveness is formed; (c) The implementation of R\&D needs to be supported by extensions, both for accelerating technology adoption and handling disease; (c) Limiting imports and stimulating the market cannot be maximized if production problems are not addressed. This policy can only minimize sharper production decline in the future. Restrictions and stimuli must still be applied when competitiveness has not yet been established. This can be seen in three indicators of assessment (relative value, production, expected profit) decreased, while import value indicators experienced an increase from business as usual.

The model is still a work in progress and has limitations that need to be addressed to give a better understanding of the industry; such as the need to incorporate the effects of weather, good agriculture practices (GAP) and the different demographics and sociologies among mandarin production centers, which also affect the mandarins demand.

\section{ACKNOWLEDGEMENT}

My sincere gratitude goes to Balitjestro, Research and Development Center for Horticulture also Research and Development Agency Ministry of Agriculture for the opportunities and support in this research. This research is dedicated to them, along with the Indonesian Mandarin farmers

\section{REFERENCES}

Abdulla, I., Arshad, F. M., Bala, B. K., Noh, K. M., \& Tasrif, M. (2014). Impact of CPO Export Duties on Malaysian Palm Oil Industry. American Journal of Applied Sciences, 11(8), 13011309. https://doi.org/10.3844/ ajassp.2014.1301.1309

Adipraja, P. F. E., \& Sulistyo, D. A. (2018). Pemodelan Sistem Dinamik untuk Prediksi Intensitas Hujan Harian di Kota Malang. Jurnal Ilmiah 
Teknologi Informasi Asia, 12(2), 137. https://doi.org/10.32815/ jitika.v12i2.272

Arsanti, I. W., Marbun, F., \& Micharam, I. (2015). Upaya Peningkatan Daya Saing Komoditas Jeruk Melalui Pendekatan System Dynamic, Studi Kasus: Sentra Produksi Kabupaten Karo dan Sentra Konsumsi DKI Jakarta. In Kebijakan Pencapaian Swasembada dan Swasembada Berkelanjutan Lima Komoditas Utama Pertanian Melalui Pendekatan Sistem Dinamik, 165-180).

Bassanezi, R. B., Montesino, L. H., Gasparoto, M. C. G., Filho, A. B., \& Amorim, L. (2011). Yield Loss Caused by Huanglongbing in Different Sweet Orange Cultivars in São paulo, brazil. European Journal of Plant Pathology, 130(4), 577586. https://doi.org/10.1007/ s10658-011-9779-1

Duflo, E; M, Kremer; J, R. (2011). Nudging Farmers to Use Fertilizer: "Theory and Experimental Evidence from Kenya." American Economic Review, 101(6), 2350-2390.

Ernawati, Lilis; Suryani, E. (2013). Analisis Faktor Produktivitas Gula Nasional dan Pengaruhnya Terhadap Harga Gula Domestik dan Permintaan Gula
Impor dengan Menggunakan Sistem Dinamik. Jurnal Teknik Pomits, 1(1), 1-7.

Ferreira, J. O., Batalha, M. O., \& Domingos, J. C. (2016). Integrated Planning Model for Citrus Agribusiness System Using Systems Dynamics. Computers and Electronics in Agriculture, 126, 1-11. https://doi.org/10.1016/j. compag.2016.04.029

Hidayatno, A., Sutrisno, A., Zagloel, Y. M., \& Purwanto, W. W. (2011). System Dynamics Sustainability Model of Palm-Oil Based Biodiesel Production Chain in Indonesia. International Journal of Engineering \& Technology, 11(June), 1-6. https://doi.org/10.3389/ fmicb.2016.00933

L,FuJia;D.,SuoCheng; L,F.(2012).ASystem Dynamics Model for Analyzing the Eco-Agriculture System with Policy Recommendations. Ecological Modelling, 227, 34-45.

Marks, S. V. (2012). Indonesian Horticultural Imports and Policy Responses-An Assessment. Washington, D.C, USA.

Meitayani, N.P.S., Adiartayasa, W., \&Wijaya, I. N. (2014). Deteksi Penyakit Citrus Vein Phloem Degeneration (CVPD) 
dengan Teknik Polymerase Chain Reaction (PCR) pada Tanaman Jeruk di Bali. E-Jurnal Agroekoteknologi Tropika, 3(2), 70-79.

Nurhadi. ( $\left(\begin{array}{llll}2 & 0 & 1 & 5\end{array}\right)$. Penyakit Huanglongbing Tanaman Jeruk (Candidatus Liberibacter Asiaticus ): Ancaman dan Strategi Pengendalian Huanglongbing Disease (Candidatus Liberibacter asiaticus) on Citrus : Threats and Control Strategy. Pengembangan Inovasi Pertanian, 8(1), 21-32.

P, Kaufmann; S, Stagl; D.W, F. (2009). Simulating The Difusion of Organic Farming Practices in Two New EU Member States. Ecological Economics, 68, 2580-2593.

Pan, Y., Smith, S. C., \& Sulaiman, M. (2018). Agricultural Extension and Technology Adoption for Food Security: Evidence from Uganda. American Journal of Agricultural Economics, 100(4), 1012-1031. https://doi.org/10.1093/ajae/ aay 012

Pardey, P. G., Alston, J. M., \& Kang, C. C. (2012). Agricultural Production, Productivity and R \& D over the Past Half Century : An Emerging New World Order. In Conference of International Association of Agricultural Economists (p. 48).

Qudrat-Ullah, H. (2012). On The Validation of System Dynamics Type Simulation Models. Telecommunication Systems, 51(2-3), 159-166. https://doi. org/10.1007/s11235-011-9425-4

Rozman, С̌., Kljajić, M., \& Škraba, A. (2015). System Dynamics Model for Conversion to Organic Farming. Journal of Siberian Federal University - Mathematics and Physics, 8(1), 6774.https://doi.org/10.17516/19971397-2015-8-1-64-74

Spreen, T. H., Baldwin, J. P., \& Futch, S. H. (2014). An Economic Assessment of The Impact of Huanglongbing on Citrus Tree Plantings in Florida. HortScience, 49(8), 1052-1055.

Sterman, J. D. (2004). Business Dynamics : Systems Thinking and Modeling for a Complex World. McGrawHill (Vol. 34). USA. https:// doi.org/10.1108/136732702 10417646

Teimoury, E., Nedaei, H., Ansari, S., \& Sabbaghi, M. (2013). A Multiobjective Analysis for Import Quota Policy Making in A Perishable Fruit and Vegetable 
Supply Chain: A System Dynamics Approach. Computers and Electronics in Agriculture, 93, 3745. https://doi.org/10.1016/j. compag.2013.01.010

Thohirah Lee Abdullah Kamaruzaman Sijam and Siti Nor Akmar, H. S., \& Abdullah. (2009). Control of Huanglongbing (HLB) Disease with Reference to Its Occurrence in Malaysia. African Journal of Biotechnology, 8(17), 4007 4015. https://doi.org/10.5897/ AJB09.678

Udry, C. (2010). The Economics of Agriculture in Africa: Notes Toward A Research Program. African Journal of Agricultural and Resource Economics, 5(1), 284-299.
Wossen, T., Abdoulaye, T., Alene, A., Haile, M. G., Feleke, S., Olanrewaju, A., \& Manyong, V. (2017). Impacts of Extension Access and Cooperative Membership on Technology Adoption and Household Welfare. Journal of Rural Studies, 54, 223233. https://doi.org/10.1016/j. jrurstud.2017.06.022

Yunna, W., Kaifeng, C., Yisheng, Y., \& Tiantian, F. (2015). A System Dynamics Analysis of Technology, Cost and Policy that Affect The Market Competition of Shale Gas in China. Renewable and Sustainable Energy Reviews, 45, 235-243. https://doi.org/10.1016/j. rser.2015.01.060 